\title{
Artistic Heritage of Kelingkan Embroidery in Malaysia: History and Development
}

Norhasliyana Hazlin Zainal Amri, Hamdzun Haron and Mohd Zaimmudim Mohd Zain

To Link this Article: http://dx.doi.org/10.6007/IJARBSS/v11-i11/11085

DOI:10.6007/IJARBSS/v11-i11/11085

Received: 10 September 2021, Revised: 04 October 2021, Accepted: 19 October 2021

Published Online: 01 November 2021

In-Text Citation: (Amri et al., 2021)

To Cite this Article: Amri, N. H. Z., Haron, H., \& Zain, M. Z. M. (2021). Artistic Heritage of Kelingkan Embroidery in Malaysia: History and Development. International Journal of Academic Research in Business and Social Sciences, 11(11), 166-180.

\section{Copyright: @ 2021 The Author(s)}

Published by Human Resource Management Academic Research Society (www.hrmars.com)

This article is published under the Creative Commons Attribution (CC BY 4.0) license. Anyone may reproduce, distribute, translate and create derivative works of this article (for both commercial and non-commercial purposes), subject to full attribution to the original publication and authors. The full terms of this license may be seen at: http://creativecommons.org/licences/by/4.0/legalcode

Vol. 11, No. 11, 2021, Pg. 166 - 180

Full Terms \& Conditions of access and use can be found at http://hrmars.com/index.php/pages/detail/publication-ethics 


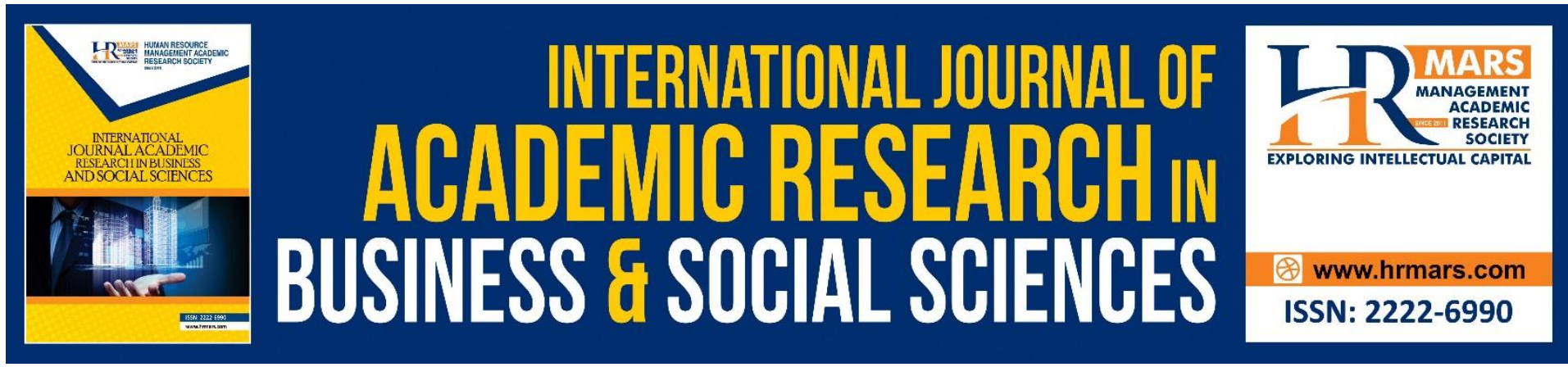

\title{
Artistic Heritage of Kelingkan Embroidery in Malaysia: History and Development
}

\author{
Norhasliyana Hazlin Zainal Amri ${ }^{1}$, Hamdzun Haron² and Mohd \\ Zaimmudim Mohd Zain ${ }^{1}$ \\ 1,3 Universiti Malaysia Kelantan, Kampus Bachok, Beg berkunci No. 01, 16300 Bachok, \\ Kelantan, Malaysia, ${ }^{2}$ Pusat Pengajian Citra Universiti, Universiti Kebangsaan Malaysia. 43600 \\ UKM Bangi, Selangor Darul Ehsan, Malaysia \\ Email: hh@ukm.edu.my
}

\begin{abstract}
Kelingkan is a form of artistic embroidery that uses metal ribbon threads, which are coated in gold and silver, and embroidered onto the surface of soft fabric. The creation of kelingkan embroidery requires a high level of accuracy and utilises all the expertise that the embroiderer possesses. Kelingkan is known as a Malay artistic heritage that is still being produced on a small scale. However, the extent to which the art of kelingkan embroidery is being continued in Malaysia today, is under question. Therefore, this research will detail the history and development of kelingkan in Malaysia, map the latest locations of kelingkan embroidery practitioners in Malaysia and explain the factors that have influenced the development of kelingkan in Malaysia. Through qualitative research methods, a field study involving the observation of artifacts and interviews with embroiderers was conducted. The findings of this research has found that the history of kelingkan embroidery in Malaysia had developed since the emergence of trade systems in the Malay World. Only three states, namely Sarawak, Selangor and Kelantan still have embroiderers who are actively making kelingkan embroidery. The development of kelingkan embroidery in Malaysia all began in the palace and spread through familial relations from generation to generation, as well as kelingkan embroidery programmes (short and long term) or incubator programmes. As an implication, the findings of this study can be used as a source of knowledge for the younger generation to continue preserving kelingkan embroidery as a heritage in Malaysia. This research can also suggest proactive efforts to continue this artistic heritage by Malay women, so that it may be preserved for the future.
\end{abstract}

Keywords: Heritage, Kelingkan, History, Embroidery, Malay Arts

\section{Introduction}

Kelingkan embroidery is a Malay artistic heritage that is still being produced on a small scale. It is one of the types of embroideries used to decorate fabric and it employs metal ribbon threads that are coated in gold. The diversity of cultures and languages spoken in Malaysia, which has 14 states, has influenced the differences in pronounciations and terms used. In Sarawak, this embroidery is known as keringkam, in Terengganu it is called teringkam, while 
in Selangor and Kelantan it is known as kelingkan. Specifically, kelingkan embroidery belongs to the different types of local textiles, which are tenunan (weaving), batik, telepuk (gold leaf), tekad (couched embroidery) and sulaman (embroidery). In Malaysia, the textile that is best known by the Malay community is the songket, and it is worn to this day, although there are various types of other textiles that have been developed and made, albeit on a small scale, especially kelingkan embroidery.

However, the question is, to what extent is kelingkan embroidery still being continued in Malaysia today? Kelingkan embroidery can be seen on Malay clothing such as the kebaya, baju kurung, head coverings like the selendang and selayah, and it is also seen on bed coverings. All these treasures are still being exhibited by museums and the National Handicraft Development Corporation. Among the dilemmas encountered are, does the younger generation know about the existence of kelingkan embroidery in line with Malaysia's progress?

\section{Research Objective}

- To describe the history and development of kelingkan art in Malaysia.

- To identify the latest mapping of kelingkan art practitioners in Malaysia.

- To analyze the factors that have influenced the development of kelingkan art in Malaysia.

\section{Kelingkan Embroidery}

The term kelingkan itself shows the influence of trade, as according to Ismail (2017), the terms 'keringkam' and 'kelingkan' originated from the Balinese words 'keling', which means a type of fabric and ' $k a m^{\prime}$ or ' $k h^{\prime} m^{\prime}$ ', which means beautiful. Meanwhile, according to Aziz (2009), the terms Keringkam and Kelingkan originated from the French term 'clinquant' which means glittering. In Indonesia, it is known by the name manto (Febby Febriyandi, 2011 and Sarkawi \& Abd. Rahman, 2014).

In Turkey, it is known as 'tel kirma' and in India it goes by the name 'makaish,' while in Egypt it is called 'tally'. Tally made in Egypt differs from embroideries made in other countries. For example, many parts of Asia or Central Asia favour traditional motifs, but the tally usually features motifs related to fairy tales and the people there. This shows the identity of Egyptian metal ribbon embroidery, which differs from those of other countries (Messiri, 2009).

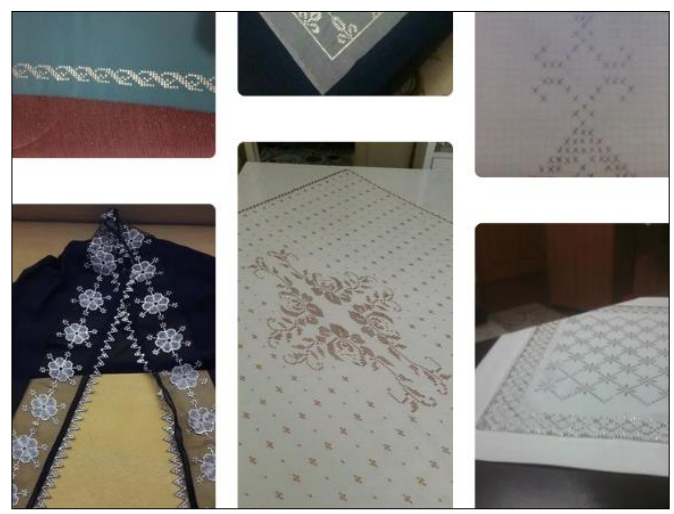

Figure 1 : Pictures of Tel Kirma taken from a website: https://tr.pinterest.com/pin/387520742921795191/ 


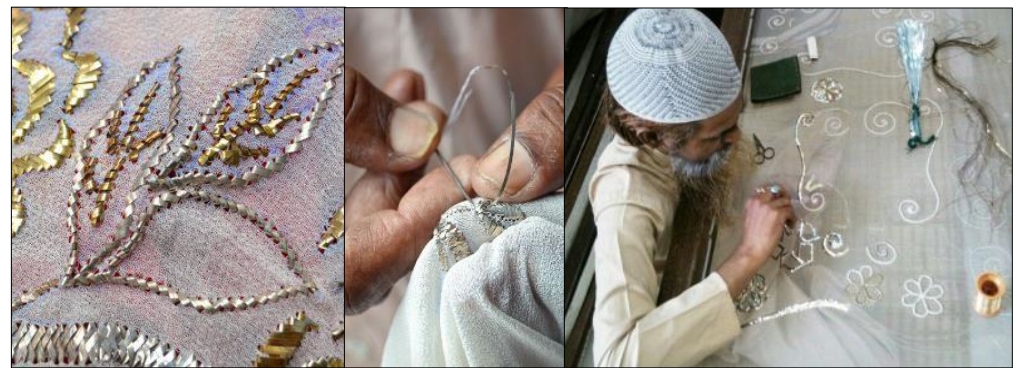

Figure 2 : Pictures of makaish or mukaish embroidery taken from a website https://www.pinterest.com/samia_ostadi/badlakasabmukaish-embroidery/

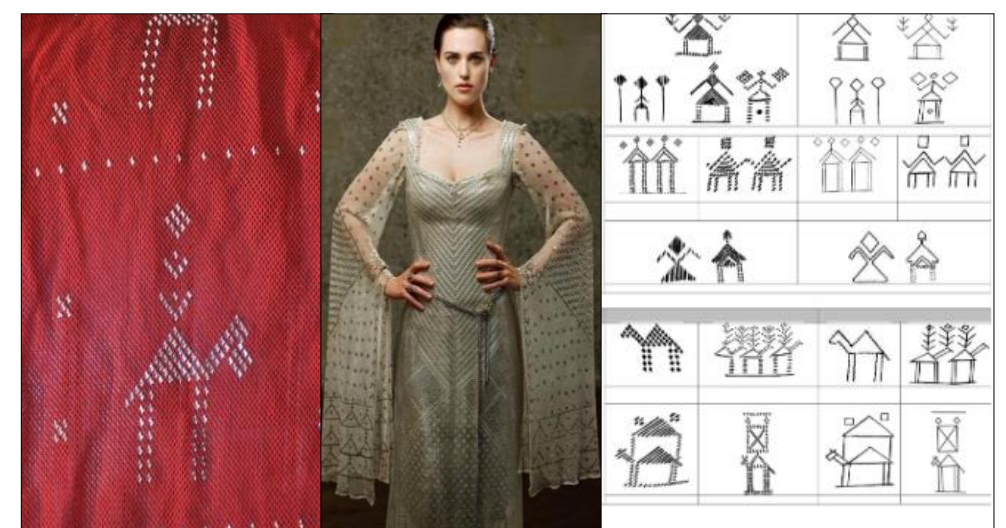

Figure 3 : Pictures of Tally taken from a journal entitled "Utilization of aesthetics value of tally woven fabric structures in fashion trends" by Elnashar et. al (2014).

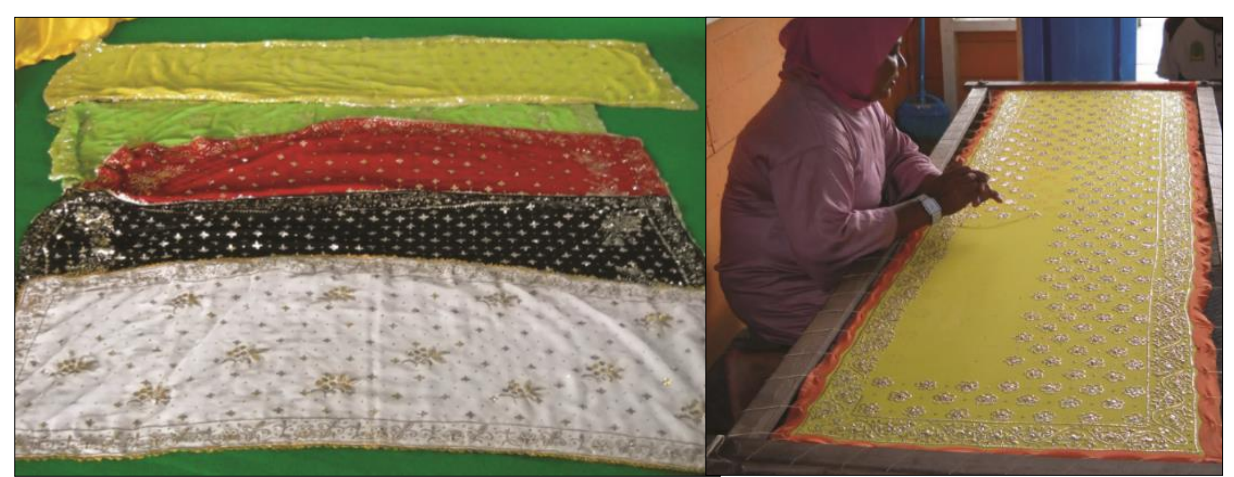

Figure 4 : Pictures taken from an article entitled "Makna Tudung Manto bagi orang Melayu Daik" by Febriyandi (2011).

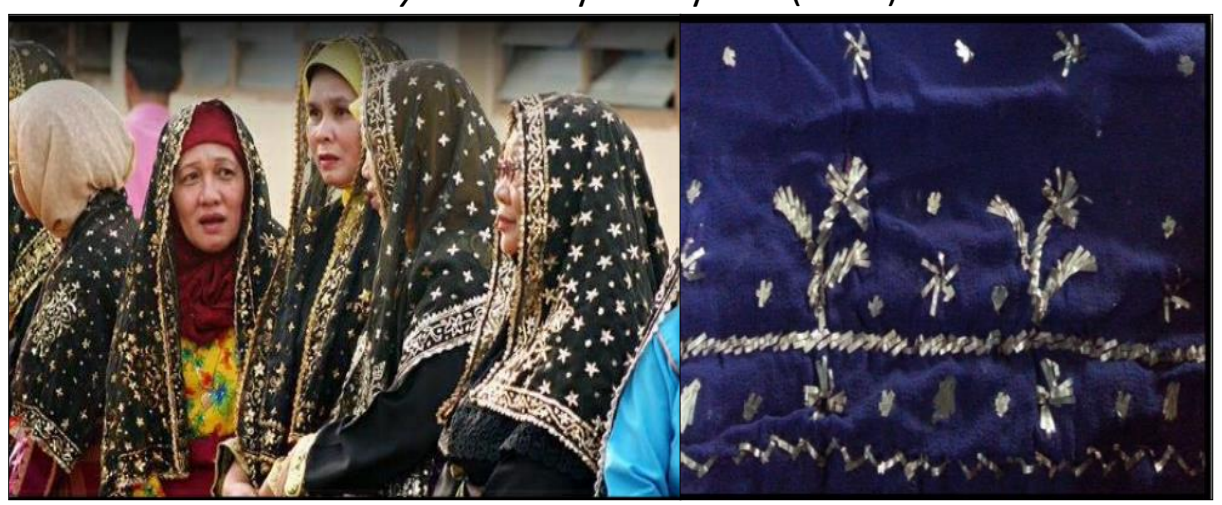

Figure 7 : Pictures taken from an article entitled "Selayah Keringkam dan Selayah Manto: Sulam Budaya Melayu Sarawak (Malaysia) dan Melayu Daik (Indonesia)" by Sarkawi \& Abd. Rahman, (2014) 


\section{Research Method}

This research was conducted in the qualitative method, while the data collection used primary and secondary sources. The data was obtained through field research involving the observation of kelingkan embroidery artifacts and interviews with kelingkan embroiderers. Field research was conducted in Malaysia, specifically in Kuala Lumpur, Selangor, Kelantan and Terengganu, as well as Kuching, Sarawak. Research sites in the Peninsular were the Museum of Malay Ethnology, Department of Museums Malaysia, Kuala Lumpur, the National Textile Museum, The Selangor Malay Customs and Heritage Corporation (PADAT), Malaysian Handicraft Development Corporation, Universiti Kebangsaan Malaysia (UKM), Universiti Putra Malaysia, Universiti Malaya (UM), and Universiti Teknologi Mara (UiTM), while those in Sarawak were the Textile Museum, Malaysian Handicraft Development Corporation Sarawak branch, Universiti Malaysia Sarawak (UNIMAS), and Universiti Teknologi Mara Sarawak. Interviews with embroiderers who are still active in Peninsular Malaysia were held in Selangor and Kelantan, while in Sarawak they were held in Kuching. In addition, the researcher also met with Malaysian Handicraft officers from the Sarawak, Kelantan and Selangor branches. Through interviews and observations, pictures of Keringkan embroidery on shawls and selayah were collected. Through field research that met with the latest kelingkan embroidery practitioners in Malaysia, it was found that only three states, namely Sarawak, Selangor and Kelantan still have embroiderers and practitioners who are actively embroidering, although on a small scale.

\section{Research Findings and Discussions}

\section{a) History and Development of the Manufacturing of Kelingkan Embroidery in Malaysia}

Malaysia has 14 states, which influences differences in the pronunciations and terms used; in Sarawak it is known as keringkam, in Terengganu it is called Teringkam, and in Selangor and Kelantan it is known as kelingkan (Ismail, 2017; Shawal, 1994; Jamal, 1992 \& Rose Dahlina Rusli, 2016). Kelingkan embroidery is part of Malay clothing. There are no written studies on kelingkan embroidery that record the date it first emerged, but earlier research, as well as notes from western colonialism, embroiderer collections, journals and verbal research data, provides clues to the emergence of kelingkan embroidery, which began with trade in the Malay Archipelago. Kelingkan embroidery is well-known in the Malay community and it began in the palace. During the reign of the Sultanate of Malacca, kelingkan embroidery referred to shawls and selayah that were used as head coverings by Malay women in the past. Kelingkan embroidery was used in head decorations or coverings to accessorise Malay clothing. Kelingkan embroidery can also be found on Malay clothes like baju kurung and baju kebaya. Since the Sultanate of Malacca, kelingkan embroidery has been used when attending ceremonies and events that required ceremonial clothing before one is allowed an audience with the sultan. If the customary dress code for head coverings isn't followed, it would be considered unkempt (Ali, 1990).

Throughout the 13 to $16^{\text {th }}$ centuries, Islam spread throughout the Malay Archipelago and reduced the influence of Hindu-Buddhism that had been established in the Malay World for centuries. As early as the $14^{\text {th }}$ century, this embroidery is said to have been made by the Malays when the Malay World was active in the textile trade with countries like Arab-Persia, Portuguese, China and India. The goods traded by foreign countries led to the introduction of materials like threads, metal ribbons, as well as silver from China and India (Maxwell \& Gittinger, 2003). In the $15^{\text {th }}$ century, during the reign of the Malay Sultanate of Malacca (Din, 2016), gold embroidery was established in the palaces of the Malay World and developed due 
to the trade systems that brought the east and west together (Ismail, 1995). Siti Zainon stated in the form of a table that heritage and design with natural materials began during the Sriwijaya era in the $7^{\text {th }}$ to $13^{\text {th }}$ centuries, using metal, copper, and gold threads, referring to the kris, gold ornaments, tekat, homes and palaces, while the Malay era from the $15^{\text {th }}$ to $17^{\text {th }}$ centuries combined external influences from China, India, Malay-Java, Java-Bugis, Makassar and others, using metal, copper, wood, gold threads and silk, referring to embroidery, weaving, sculpture, architecture and carving (Zainon, 1986).

Renowned textile researchers, such as Maxwell \& Gittinger, (2003); Leigh (1982) and Hall (1968) believe that Southeast Asia's metal embroidery was influenced by Ottoman and Mughal empires through trade and diplomatic relations (Abdul Ghani and Zakaria, 2013). The influence of Ottoman Turkey began to spread in the $16^{\text {th }}$ century (Sarkawi \& Abd. Rahman, 2016). In 2017, gold and silver metal ribbons for use in kelingkan embroidery in Malaysia could only be obtained from Arab Street in Singapore and a single kelingkan shawl would be sold for a high price due to the difficulties in obtaining the tools needed. Meanwhile, in Sarawak, the materials can be obtained in Jalan India, at the only shop that sells kelingkan threads and needles in Malaysia, which is Syarikat Salih Ahmah number 27 in Kuching. Syarikat Salih Ahamad sells gold and silver metal ribbons that can be purchased for RM20, RM40 and RM140, but to make high-quality kelingkan embroidery, only the best metal ribbons priced at RM140 will do. Through interviews, kelingkan embroiderers have stated that the name kelingkan may have originated from India. From a historical angle, trade records and the Sultanate of Malacca have stated that the rulers of Malacca were descendants of Raja Iskandar Zulkarnian, who was Hindustani, Tun Seri Lanang, the premiere Malay poet and Mani Purindum, who was a Malay poet who originated from India and was of Keling descent (Shellabear, 1976). Books written by Anwar Din state that the founder of the Malay Sultanate of Malacca and the Malay poet were of Indian descent (Din, 2016). This may be considered as one of the reasons why the term kelingkan is known in the Malay World, but there is no solid evidence besides descent.

Through interviews, Siti Zainon Ismail states that kelingkan embroidery is related to gold thread embroidery as the materials used are from gold and silver ribbons (Ismail, 2017). Therefore, all references related to gold embroidery can be used as evidence and the basis of kelingkan embroidery, because although the pronunciations are different, the meanings are the same. The differences in pronunciations or terms are as such, in Sarawak it is called Keringkam (Ismail, 1996; Josmani et. al, 2012; Pawi, 2014; Norseha, 2012; Sarkawi \& Abd. Rahman, 2014, 2016 ). Terengganu uses the term teringkam or terekam (Ismail, 1994, Shawal, 1994, Sarkawi \& Ab. Rahman, 2014; 2016), while Selangor and Kelantan use the name kelingkan (Jamal, 1992 and Rusli et. al 2016) and kelengkan (Sarkawi \& Abd. Rahman, 2016). Some in Kelantan know it as kelingkam and kelengkang (Sarkawi \& Abd. Rahman, 2016).

According to Frank Swettentham (1929), at the end of the $19^{\text {th }}$ century, Raja Maimunah wore traditional Malay clothing that included tekat shoes and kelingkan shawls. In Selangor, kelingkan was introduced in 1904 by Allahyarhamah Permaisuri Tengku Ampuan Jameah and it was continued by Tengku Ampuan Rahimah in the 1960s. The Tengku Ampuan's father was descended from the Selangor royal family and her mother was born into the courts of the Langat palace. As queen of Selangor, she brought aestheticians and the kelingkan artform to be developed in the Selangor palace. As kelingkan embroidery was inherited by female members of the royal family, a master that has been continuing this tradition for 40 years is YM Raja Akmar (Siti Zainon 2010). In the Peninsular, the Malay Ethnology Museum, the Department of Museums Malaysia, Kuala Lumpur, the Islamic Arts Museum Malaysia, the 
National Textile Museum and the Malay Customs and Heritage Corporation still display kelingkan embroidery for the reference of younger generations.

Meanwhile, in the Borneo islands, especially in Sarawak, there is no exact recorded date, but the Sarawakian Malays have been wearing kelingkan head coverings since before the $19^{\text {th }}$ century (Brooke, 2018). Evidence of Malay Sarawakian women wearing kelingkan selayah to cover their heads can be seen at the Textile Museum of Sarawak, which exhibits a picture of Lady Ranee Margaret Brooke with Malay Sarawakian women wearing kelingkan shawls and through the writings of Lady Margaret Brooke. In her book My Life in Sarawak, Ranee Margaret of Sarawak talks about her experiences wearing selayah keringkam and songket Sarawak. It is clear that in the Malay Peninsula, kelingkan embroidery had become an identity for Malay women in the past. They respected Malay culture and the products of kelingkan embroidery from that era are renowned and pioneered by the women of the palace. On the island of Borneo, specifically in Sarawak at the Sarawak Textile Museum and the Malaysian Handicraft Development Corporation Sarawak branch, exhibitions on kelingkan embroidery are still being organised to this day.

It can be concluded that in Malaysia, which was once known as the Malay Penisula, the history of kelingkan embroidery began when trade occurred and developed with the passage of time. Influences in kelingkan embroidery remained intact due to the arrival of Islam in the Malay Peninsula that preserved kelingkan embroidery with the use of motifs from the natural world. Ismail (1995) also talked about the Malay community's awareness towards the elements of nature, particularly the flora and fauna that played an important role in the Malay thought process, which inspired them to create decorative arts, especially kelingkan embroidery. Due to the expertise and skilled hands of kelingkan embroiderers and the beauty of their creations, kelingkan embroidery must be valued and carefully preserved by the community. The identity of the Malay community is reflected in kelingkan embroidery. The effort, diligence, perseverance and meticulousness of the embroiderers in creating kelingkan embroidery makes this artform even more valuable.

The diversity of the language, lifestyle and culture of the majority of Malaysians is pioneered by the Malay community. This shows that Malaysia itself has a uniqueness, especially in the arts that are available in Malaysia. Through previous research, we know about the beginnings of kelingkan embroidery in Malaysia, which survives to this day. The latest locations for surviving kelingkan embroidery are in Sarawak, Selangor, Kelantan, Terengganu and Negeri Sembilan (Sarkawi \& Abd. Rahman, 2016). Research findings through written articles by Sarkawi \& Abd. Rahman that have traced kelingkan embroidery in Malaysia and Indonesia, have made it easier for this research to be conducted (Sarkawi \& Abd. Rahman, 2016). This developmental study is focused on mapping the latest kelingkan practitioners in Malaysia.

Developments that have occurred in kelingkan embroidery can be seen in the exhibitions conducted, which enable younger generations to know kelingkan embroidery, such as the National Handicraft Day that is held every February and the Glorious Textile of the Islamic World exhibition held at the Putrajaya International Convention Centre (PICC) from 1 to 11 December 2016, which exhibited kelingkan in Malaysia. According to interviews with embroiderers, most kelingkan embroidery is made according to commissions by the local Malay community, for use at weddings, official ceremonies, as gifts or personal collections, although they are sold at a high price. In the past, the use of keringkam embroidery was limited to royalty and it was not used by normal citizens. Through change, now normal citizens can own it, unlike before when it was the preserve of nobility and royalty. 
Each state can be differentiated through materials, tools and motifs that are different in each state. The tools that are commonly used for embroidery are usually gold or silver ribbons, needles, gauze fabric and a wood frame. Wood frames are not used in Selangor, but only in Sarawak and Kelantan.

Requests for kelingkan embroidery continue to this day although it is on a small scale. Orders for kelingkan shawls and selayah for weddings are most popular among Malaysians, although it is sold for a high price starting from RM1000 and above.

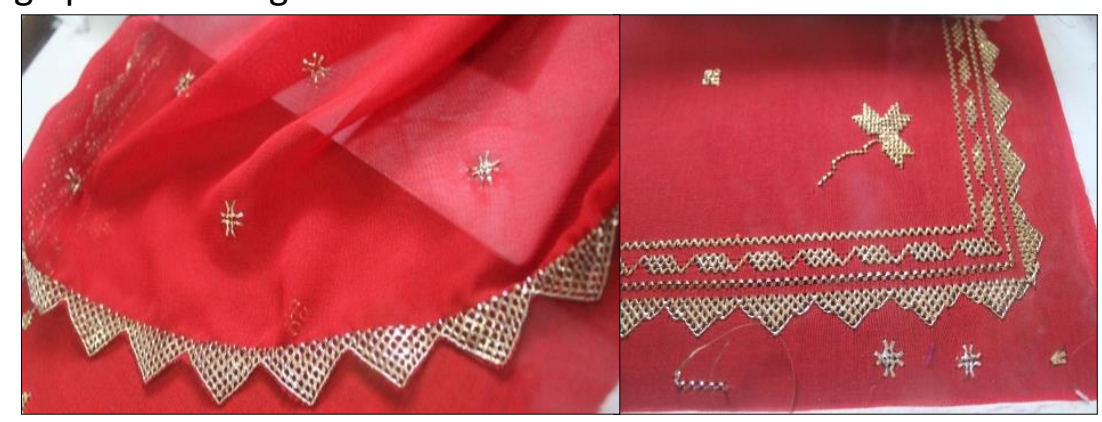

Figure 5 : Kelingkan embroidered shawl and selayah from Sarawak

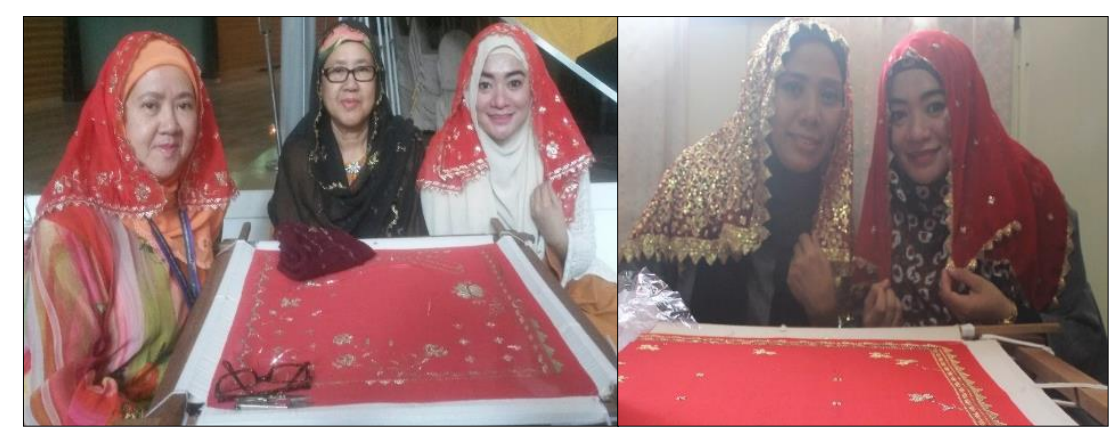

Figure 6 : The researcher with embroiderers who are still actively embroidering kelingkan.

Source: Field Research, 2016

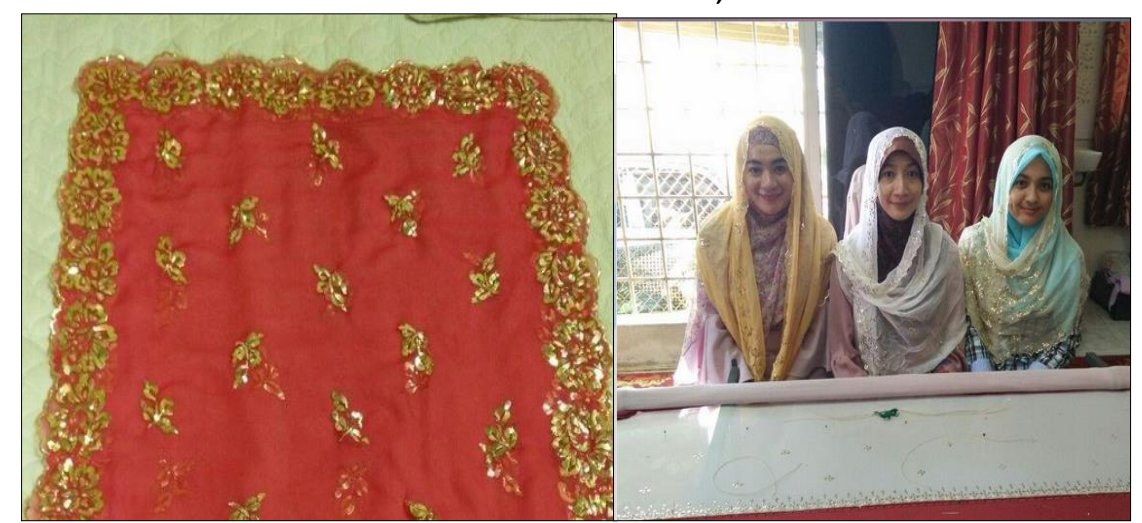

Figure 8: Shawl from Kelantan and the researcher with an embroiderer who is still actively embroidering kelingkan.

Source: Field Research, 2017 


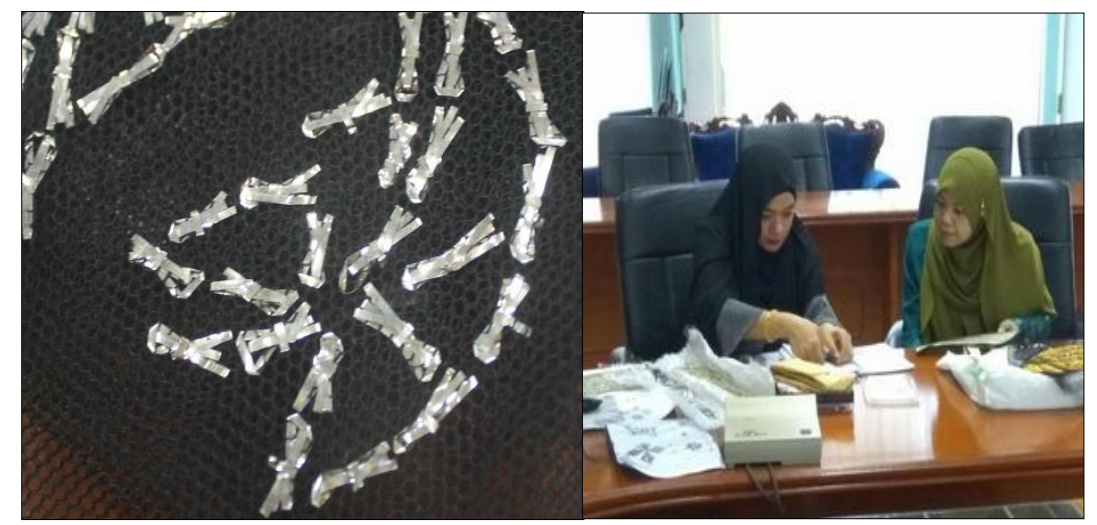

Figure 9 : The ribbon technique of Selangor's kelingkan shawls and the researcher learning to embroider at PADAT or the Selangor Malay Customs and Heritage Corporation.

Source: Field Research, 2017

\section{b) Mapping the latest kelingkan practitioners in Malaysia.}

Malaysia has 14 states, but only 3 of those states still have kelingkan practitioners or embroiderers who are still active, which are in Sarawak, Selangor and Kelantan. These findings are in line with a study that mapped kelingkan head coverings in Malaysia, and mapped the location of kelingkan head coverings in Malaysia and Indonesia. The findings of this journal is on tracing the existence of kelingkan embroiderers and head coverings in Malaysia and Indonesia. This journal is a reference to this research, which focuses only on Malaysia. This journal only records the discovery of artifacts in Sarawak, Selangor, Kelantan, Terengganu and Negeri Sembilan, meanwhile the existing embroiderers are located in Sarawak, Kelantan and Selangor (Sarkawi \& Abd. Rahman, 2016). The discovery of states that still have embroiderers in that journal aligns with the findings of this study. The findings of this study mapped the latest kelingkan embroidery practitioners in Malaysia.

Table 1 explains the mapping of the latest kelingkan embroidery practitioners in Malaysia, which refers to practitioners or embroiderers that are still actively embroidering in Sarawak, Selangor and Kelantan. The total number of kelingkan practitioners is 32 people, or 16 people in Sarawak, 12 people in Selangor and 4 people in Kelantan. The total percentage of practitioners in Malaysia is shown in Pie Chart 1. It shows that there are still practitioners making kelingkan embroidery and this mapping makes it easier for enthusiasts and researchers to find kelingkan practitioners. There is a total of 32 kelingkan embroidery practitioners. Kelingkan embroidery originated from the palace and developed through familial relations from generation to generation and incubator programmes. A second finding to this study is on practitioners who have familial relations from generation to generation and practitioners who followed incubator programmes. 
Table 1: Mapping of the latest Kelingkan Embroidery Practitioners in Malaysia

\begin{tabular}{|c|c|c|c|}
\hline No & State & Name of Practitioner/ Practitioner & Total \\
\hline 1 & Sarawak & $\begin{array}{l}\text { Salbiah Binti Muhi } \\
\text { Zainab Binti Muhi } \\
\text { Mastura @ Masnah Sidek } \\
\text { Sharifah Zuriana Binti Wan Junaidi } \\
\text { Nora Syamsiah Binti Zaidel } \\
\text { Dorris Hilda } \\
\text { Azyla Adami } \\
\text { Fazilah Binti Abdullah @Olivia } \\
\text { Kamriah Binti Jamel } \\
\text { Zaiton Binti Morshidi } \\
\text { Halimah Binti Sukri } \\
\text { Ros Binti Salleh } \\
\text { Faruq Bin Kadir } \\
\text { Saiful Badrie Bin Kadir } \\
\text { Fatimah Binti Katon } \\
\text { Julia Binti Mahadi }\end{array}$ & 16 people \\
\hline 2 & Selangor & $\begin{array}{l}\text { Raja Nor Akma Raja Bahari } \\
\text { Muhamad Sharif Bin Othman } \\
\text { Jasni Termizi Bin Abdullah } \\
\text { Siti Hadrawati Binti Kasi } \\
\text { Norhamizah Binti Mohamad } \\
\text { Tanty Marlena Binti Abdullah } \\
\text { Norasidah Binti Jonit } \\
\text { Suzana Binti Ahmad Pandi } \\
\text { Nazira Binti Radzali } \\
\text { Norazleeta Binti Ismail } \\
\text { Sophiah Binti Amaluddin } \\
\text { Ruhaizan Bin Anen }\end{array}$ & 12 people \\
\hline 3 & Kelantan & $\begin{array}{l}\text { Nik Rahimah Binti Nik Idris } \\
\text { Nik Marhammah Binti Nik Idris } \\
\text { Robitah Binti Hashim } \\
\text { Nik Nurul Amalina Nik Mohd Nizam }\end{array}$ & 4 people \\
\hline \multicolumn{3}{|c|}{ Total number of practitioners } & 32 people \\
\hline
\end{tabular}

Pie Chart 1 shows the overall percentage of practitioners in Malaysia. Sarawak shows that highest percentage with $50 \%$, followed by Selangor with $37 \%$ and the lowest percentage was at $13 \%$. This may have been due to a love and appreciation for kelingkan heritage within the Sarawak community. Kelingkan head coverings are still exhibited at the Textile Museum in Sarawak, where in the past, the wife of Sarawak's Head of State wore kelingkan shawls and it became a tradition in Sarawak to this day. 


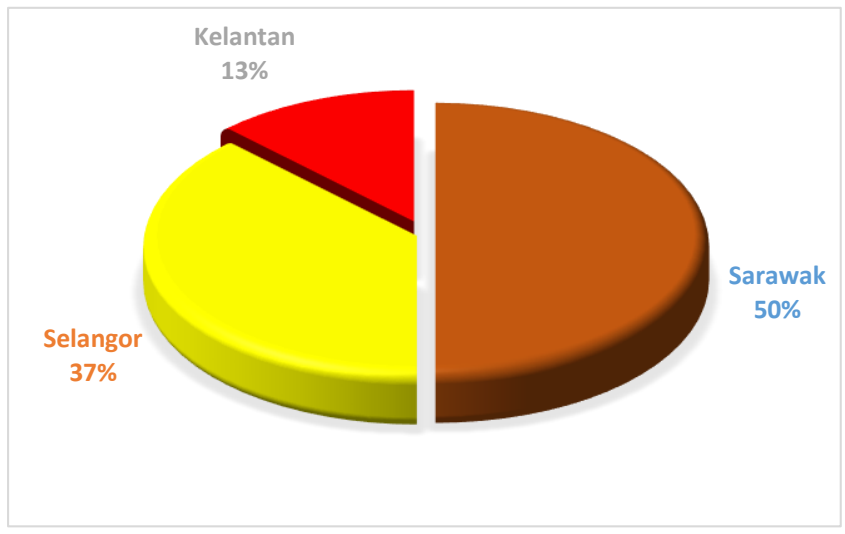

Pie Chart 1: Total percentage of practitioners in Malaysia

Table 2 explains the mapping of kelingkan embroidery practitioners through familial relations from generation to generation and incubator programmes, which comes to a total of 32 practitioners in Malaysia from the three states with the most kelingkan practitioners.

Table 2 Mapping of Kelingkan Embroidery Practitioners Through Familial Relations From Generation to Generation and Kelingkan Embroidery Programmes (short term and long term) or Incubator Programmes.

\begin{tabular}{|c|c|c|c|c|}
\hline \multirow[t]{2}{*}{ No } & \multirow[t]{2}{*}{ State } & \multirow[t]{2}{*}{ Practitioner } & \multicolumn{2}{|c|}{ Relation } \\
\hline & & & $\begin{array}{c}\text { Familial / } \\
\text { generation to } \\
\text { generation }\end{array}$ & $\begin{array}{l}\text { Kelingkan } \\
\text { embroidery } \\
\text { programmes } \\
\text { (short and } \\
\text { long term) or } \\
\text { incubator } \\
\text { programmes }\end{array}$ \\
\hline \multirow[t]{14}{*}{1} & \multirow[t]{14}{*}{ Sarawak } & $\begin{array}{l}\text { Cik Hajah Salbiah Binti Muhi } \\
\text { (skilled in keringkam embroidery) }\end{array}$ & $\sqrt{ }$ & \\
\hline & & $\begin{array}{l}\text { Cik Zainab Binti Muhi } \\
\text { (skilled in keringkam embroidery) }\end{array}$ & $\sqrt{ }$ & \\
\hline & & $\begin{array}{l}\text { Hajah Mastura @ Masnah Sidek } \\
\text { (skilled in keringkam embroidery) }\end{array}$ & $\sqrt{ }$ & \\
\hline & & Sharifah Zuriana Binti Wan Junaidi & & $\sqrt{ }$ \\
\hline & & Nora Syamsiah Binti Zaidel & $\sqrt{ }$ & \\
\hline & & Dorris Hilda & & $\sqrt{ }$ \\
\hline & & Azyla Adami & $\sqrt{ }$ & \\
\hline & & Fazilah Binti Abdullah @Olivia & & $\sqrt{ }$ \\
\hline & & Kamriah Binti Jamel & & $\sqrt{ }$ \\
\hline & & Halimah Binti Sukri & & $\sqrt{ }$ \\
\hline & & Zaiton Binti Morshidi & & $\sqrt{ }$ \\
\hline & & Ros Binti Salleh & & $\sqrt{ }$ \\
\hline & & Faruq Bin Kadir & & $\sqrt{ }$ \\
\hline & & Saiful Badrie Bin Kadir & & $\sqrt{ }$ \\
\hline
\end{tabular}




\begin{tabular}{|c|c|c|c|c|}
\hline & & Fatimah Binti Katon & & $\sqrt{ }$ \\
\hline & & Julia Binti Mahadi & & $\sqrt{ }$ \\
\hline \multirow[t]{12}{*}{2} & \multirow[t]{12}{*}{ Selangor } & $\begin{array}{l}\text { Y M Raja Nor Akma Raja Bahari (Mak } \\
\text { Engku) } \\
\text { (skilled in kelingkan embroidery) }\end{array}$ & $\sqrt{ }$ & \\
\hline & & Muhamad Sharif Bin Othman & $\sqrt{ }$ & \\
\hline & & Jasni Termizi Bin Abdullah & $\sqrt{ }$ & \\
\hline & & Siti Hadrawati Binti Kasi & & $\sqrt{ }$ \\
\hline & & Norhamizah Binti Mohamad & & $\sqrt{ }$ \\
\hline & & Tanty Marlena Binti Abdullah & & $\sqrt{ }$ \\
\hline & & Norasidah Binti Jonit & & $\sqrt{ }$ \\
\hline & & Suzana Binti Ahmad Pandi & & $\sqrt{ }$ \\
\hline & & Nazira Binti Radzali & & $\sqrt{ }$ \\
\hline & & Norazleeta Binti Ismail & & $\sqrt{ }$ \\
\hline & & Sophiah Binti Amaluddin & & $\sqrt{ }$ \\
\hline & & Ruhaizan Bin Anen & & $\sqrt{ }$ \\
\hline \multirow[t]{4}{*}{3} & \multirow[t]{4}{*}{ Kelantan } & $\begin{array}{l}\text { Hajah Nik Rahimah Binti Nik Idris } \\
\text { (Adi Guru kelingkan embroidery 2013) }\end{array}$ & $\sqrt{ }$ & \\
\hline & & Nik Marhammah Binti Nik Idris & $\sqrt{ }$ & \\
\hline & & Robitah Binti Hashim & $\sqrt{ }$ & \\
\hline & & Nik Nurul Amalina Nik Mohd Nizam & $\sqrt{ }$ & \\
\hline \multicolumn{3}{|c|}{ Total } & 12 People & 20 People \\
\hline
\end{tabular}

Pie Chart 2 shows the total percentage of practitioners in Malaysia through Familial Relations From Generation to Generation and Kelingkan Embroidery Programmes (long and short term) or Incubator Programmes. Kelingkan embroidery programmes (long and short term) or Incubator programmes account for the highest percentage at $63 \%$ and Familial Relations from Generation to Generation accounted for $37 \%$. This occurred due to the help and support of the government in matters related to kelingkan embroidery, so that it endures in Malaysia. The government has conducted various programmes, such as handicraft programmes and training embroiderers through incubator programmes. Familial relations from generation to generation must also be preserved because these embroiderers are historical references and kelingkan embroidery is a part of their souls.

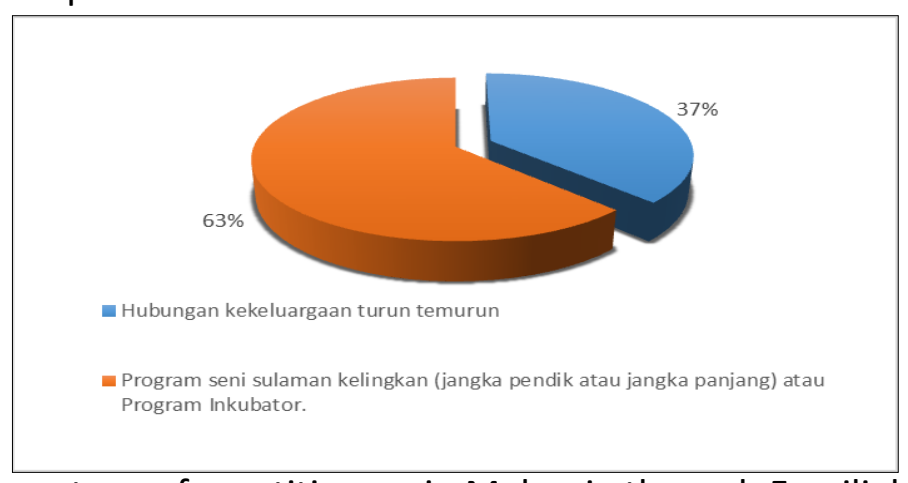

Pie Chart 2: Total percentage of practitioners in Malaysia through Familial Relations from Generation to Generation and Kelingkan Embroidery Programmes (short and long term) and Incubator Programmes. 


\section{c) Factors that Influence the Development of Kelingkan in Malaysia}

The development of kelingkan embroidery in Malaysia is influenced by several factors, including:

\section{Trade and Colonialism}

Artistic processes occurred in Malaysia due to the trade and colonialism that happened in the Malay Peninsula in the past. Many changes occurred, especially in kelingkan embroidery, because the materials for making kelingkan were obtained through trade and records on textiles were noted down by western researchers, for example Crawfurd who mentioned clothing, whereby weaving was a "useful art" in the "history of indian Archipelago 1967, Sir Frank Swettenham 'The Malay : his custom, prejudice, art, language, and literature in British Malay an account of the origin and progress of the British influence in Malaya in 1929 that talks about clothing from the perspective of materials used, shape, function and symbolism.

\section{Government and Rulers}

Government policies for maintaining heritage and culture are still being carried out today. Various efforts have been introduced to develop handicrafts in Malaysia. The government has also given financial, industrial training, promotional and marketing assistance, as well as strived to elevate heritage arts. The latest effort by the government, with cooperation from Dewan Bahasa dan Pustaka (DBP), was to organise the Cultural Congress 2017 entitled Budaya Tinggi Paksi Tamudun Bangsa, which was held on 15 April 2017 at Universiti Kebangsaan Malaysia for the second time, as it was last organised in 1971. The Cultural Congress looked for new ideas in preserving culture and strengthening Malay customs that is being increasingly eroded, and the voice of the people could be heard at the congress, which involved more than 80 government departments, 350 NGOs, and students from all universities in Malaysia. The government and statutory bodies in preserving Malay artistic treasures. The Cultural Congress was officiated by YAB Prime Minister, Dato' Sri Mohd Najib Tun Abdul Razak. It is clear that funding and the concern of the Malaysian government has led to various changes in kelingkan embroidery, be it negative or positive.

\section{The Nation's modernisation process}

Fashion's rapid development has caused the growth of kelingkan embroidery as we see it today, as it is an artistic tradition that is only known to some in the community. In the past, kelingkan embroidery was worn only by royalty, but the changes that have been made today make it possible for normal citizens to wear kelingkan embroidery that was once the preserve of royalty. Various efforts have been made by the government and if there is no interest among the younger generation, this artistic tradition will continue to be eroded. For example, the kelingkan embroidery that exists today are mainly shawls and selayah that are worn at weddings and this is a good change, although the embroideres have introduced many modifications in kelingkan embroidery patterns that have become the embroiderer's identity, which differs from the traditional motifs of the past, but still retain the use of flora in line with Islamic teachings.

\section{Conclusion}

In conclusion, the history and development of kelingkan embroidery is very fascinating and special. It should be the pride of not only the Malay people, but all Malaysians. Kelingkan embroidery is a heritage that should be preserved and not only seen from a commercial 
standpoint, but also for its value as a heritage and art that reflects Malayness. Therefore, efforts to map kelingkan practitioners must be done to make it easier for future researchers who are interested to conduct research, so that kelingkan embroidery can continue and attract younger generations, be it through familial relations from generation to generation and kelingkan embroidery programmes (short and long term) or incubator programmes. Both relations can help preserve and ensure the continuity of this heritage so that it will not be forgotten due to modernity. This handicraft is very valuable and must be appreciated by all, because the lack of written data has caused younger generations to be unaware of the existence of this cultural treasure. Programmes related to handicrafts, like kelingkan embroidery, should be conducted during celebrations and historical events. Large-scale annual handicraft programmes and technological advancements like social media can also be used to make the kelingkan better known and valued.

\section{Corresponding Author}

Dr. Hamdzun Haron

School of Liberal Studies, Universiti Kebangsaan Malaysia, 43600 Bangi, Selangor

Email: hh@ukm.edu.my

\section{References}

Din, A. (2016). Asas Kebudayaan dan Kesenian Melayu, Bangi: Universiti Kebangsaan Malaysia.

Aziz, A. (2009). Rupa dan Gaya Busana, Melayu, Bangi: Universiti Kebangsaan Malaysia.

Pawi, A. A. (2014). Sarawak Malay Material Culture and Their Welthanschauung: some Preliminary Research Themes and Findings. Thailand: Faculty of Liberal Arts, Prince of Songkla University.

Brooke, M. R. (2018). My Life in Sarawak. Lomdon: Franklin Classics.

Elnashar, E., Yoakim, J. B., Fathy, M., \& Shoman, A. (2014). Utilization of aesthetics value of tally woven fabric structures in fashion trends. Journal of the Faculty of Technics and Technologies, Vol. 2, No. 4: 317-328.

Febriyandi, F. Y. S. (2011). Makna Tudung ManTo Bagi Orang Melayu Daik. Widyariset, Pusbindiklat Peneliti-LIPI: The National Training and Education Center for Researchers Development - Indonesian Institutes of Sciences, Vol. 14 No.1: 101-112.

Josmani, A. D. S., Kibat, S. A., Halamy, S., \& Sue Lin, V. C. (2012). Selayah Keringkam,the traditional embroidery of the Sarawak Malays. Proceedings of the $13^{\text {th }}$ international Joint World Cultural Tourism Conference, College of Management Bangkok, University of Phayao. Thailand, 12-14 oktober, pp. 32-37.

Maxwell, R., \& Gittinger, M. (2003). Textiles of South East Asia: Tradition, trade and transformation. Hong Kong: Periplus.

Ali, M. K. (1990). Barang Kemas Melayu Tradisi. Kuala Lumpul : Dewan Bahasa dan Pustaka

Messiri, N. (2009). The Making of Traditional Artist: The Art of Tally and Sustainable Development. Cairo : ESFT.

Rusli, R. D., Nawawi, N. M. (2016). Uniqueness of Malay Traditional Embroidery: Kelingkan. Proceedings of the 2nd International Colloquium of Art and Design Education Research (iCADER 2015). pp 625-635.

Ismail, S. Z. (1986). Reka Bentuk Kraf Tangan Melayu Tradisi. Kuala Lumpur: Dewan Bahasa dan Pustaka. 
Ismail, S. Z. (1994). The Art of Embroidery, in Shamira Bhanu (Eds.), The Craft of Malaysia. Singapore: Didier Millet. pp. 139-147.

Ismail, S. Z. (1995). Sulaman Benang Emas: Satu Kajian Seni Hias Melayu. Journal Akademika. 46: 47-73.

Ismail, S. Z. ( 1996) Baju Melayu Johor. Johor Bahru: Yayasan Johor.

Sarkawi, S., \& Abd. Rahman, N. (2014). Selayah Keringkam dan Selayah Manto: Sulam Budaya Melayu Sarawak (Malaysia) dan Melayu Daik (Indonesia). Proceedings of the First National Conference of Malay Excellence. Hotel Armada Petaling Jaya, 2-3 Disember 2014. pp. 188-209.

Sarkawi, S., \& Abd. Rahman, N. (2016). Jejak Sulaman Kelingkan di Malaysia Dan Indonesia. Jurnal Pengajian Melayu, Jilid 27:Universiti Malaya: Kuala Lumpur, Vol. 27 No. 1: pp. 4569.

Jamal, S. A. (1992). Rupa dan Jiwa. Kuala Lumpur: Dewan Bahasa dan Pustaka.

Shawal, Z. (1994). Busana Melayu. Kuala Lumpur: Jabatan Muzium dan Antikuiti Malaysia. 